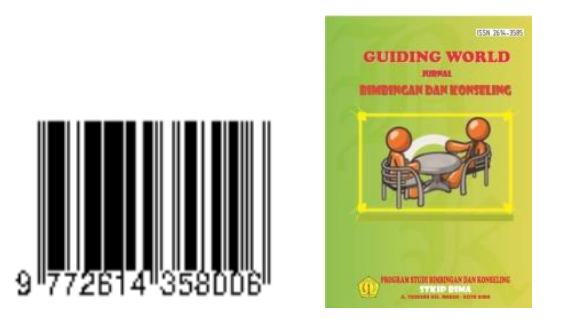

E-ISSN: 2614-3585

\title{
Peran guru bimbingan dan konseling dalam mengatasi prokrastinasi pada peserta didik di SMA Negeri 2 Kota Bima
}

\author{
Sarbudin \\ Prodi Bimbingan dan Konseling, Sekolah Tinggi Keguruan Dan Ilmu Pendidikan (STKIP Bima) \\ Email: sarbudin@gmail.com
}

\begin{abstract}
Abstrak
Penelitian ini di latar belakangi oleh adanya beberapa peserta didik di SMA Negeri 2 Kota Bima yang mengalami prokrastinasi, diantaranya tidak mengerjakan tugas, menganggap enteng/menunda mengerjakan tugas sampai saat terakhir untuk mengumpulkan tugas, sehingga berdampak pada turunya prestasi peserta didik. Tidak mengerjakan tugas, menganggap enteng/menunda mengerjakan tugas sampai saat terakhir untuk mengumpulkan tugas, sehingga berdampak pada turunya prestasi peserta didik. Rumusan masalah dalam penelitian ini adalah apa penyebab peserta didik mengalami prokrastinasi di SMA Negeri 2 Kota Bima Tahun Pelajaran 2019/2020?, dan tujuan dari penelitian ini adalah untuk mengetahui faktor-faktor yang menyebabkan prokrastinasi pada peserta didik di SMA Negeri 2 Kota Bima. Penelitianinimenggunakanmetodepenelitiankualitatifdeskriptif, dengan Teknik pengumpulan data menggunakan metode observasi, wawancara dan dokumentasi. Sumber data dalam penelitian ini adalah guru bimbingan dan konseling.

Adapun teknik analisis data dalam penelitian ini adalah reduksi data, display data, dan verifikasi. Berdasarkan hasil penelitian yang peneliti temukan dapat disimpulkan bahwa guru bimbingan dan konseling berperan penting dalam mengatasi prokrastinasi pada peserta didik yang awalnya belum mengetahui dampak dari menunda-nunda mengerjakan tugas, setelah diberikan pemahaman dan bimbingan ternyata membuahkan hasil yang positif, peserta didik jadi mengetahui akibat dari menunda-nunda mengerjakan tugas dan menjadikan peserta didik percaya diri dengan kemampuan yang dimiliki mereka, guru bimbingan dan konseling berharap peserta didik tidak lagi mengulangi untuk menunda-nunda mengerjakan tugas karena akan sangat berpengaruh pada nilai rendah
\end{abstract}

Kata Kunci: Guru Bimbingan dan Konseling, Prokrastinasi

\section{PENDAHULUAN}

Pendidikan berperan penting dalam meningkatkan kualitas sumber daya manusia yang mendukung kemajuan bangsa dan negara. Menurut Undang-undang Sisdiknas No. 20 tahun 2003 "Pendidikan adalah usaha sadar dan terencana untuk mewujudkan suasana belajar dan proses pembelajaran agar peserta didik secara aktif mengembangkan potensi dirinya 

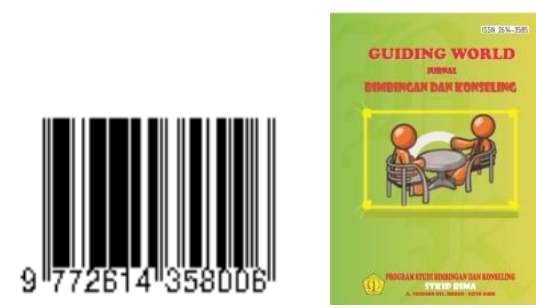

E-ISSN: 2614-3585

untuk memiliki kekuatan spiritual keagamaan, pengendalian diri, kepribadian, kecerdasan, ahlak mulia, serta keterampilan yang diperlukan dirinya dan masyarakat (Kemendikbud,2013).

Di sekolah terdapat Guru Bimbingan dan Konseling yang membantu siswa dalam mengatasi masalah yang sedang dialami oleh siswa dilingkungan sekolah maupun diluar lingkungan sekolah.Nurihsan (2009:30) Guru Bimbingan dan Konseling adalah guru yang memiliki kemampuan dan kualitas kepribadian yang baik, memiliki pengetahuan dan keahlian professional tentang pelayanan bimbingan dan konseling, serta pendidikan psikologi yang sesuai dengan tugas dan profesinya.Sedangkan menurut Undang-Undang Sistem Pendidikan Nasional No. 20 tahun 2003 pasal 1 ayat 6 menyatakan guru Bimbingan dan konseling adalah konselor sekolah, konselor adalah pendidik. Pendidik adalah tenaga kependidikan yang berkualitas sebagai guru, dosen, konselor, pamong, belajar, widyaiswara, tutor, instruktur, fasilitator, dan sebutan lain yang sesuai dengan ke khususannya,sertaberpartisipasi dalam menyelenggarakan pendidikan.

Bimbingan dan Konseling adalah proses bantuan yang diberikan oleh pembimbing (konselor) kepada individu(konseli) melalui pertemuan tatap muka atau hubungan timbal balik antara keduanya,supaya konseli mempunyai kemampuan atau kecakapan melihat dan menemukan masalahnya serta mempunyai kemampuan memecahkan masalahnya sendiri (Tohirin 2013:25).

Adapun bentuk layanan yang digunakan di dalam penyelenggaraan bimbingan dan konseling: yaitu layanan Orientasi, Informasi, Penempatan dan penyaluran, konsultasi, Konseling individual, Bimbingan kelompok, Konseling kelompok, Penguasaan konten, Mediasi, dan Advokasi, (prayitno,2009).Yang menyelenggarakan layanan adalah guru bimbingan dan konseling.

Dari pengertian di atas dapat di simpulkan bahwa guru Bimbingan dan Konseling merupakan seorang pendidik yang memiliki tugas membantu siswa dalam mengatasi masalah yang sedang dialami siswa dilingkungan sekolah maupun diluar lingkungan sekolah. Fungsi guru bimbingan dan konseling adalah membantu mengembangkan kemampuan belajar, agar menjadikan peserta didik mandiri dalam belajar.

Adapun peranGuru bimbingan dan konseling yaitu bertanggung jawab untuk membimbing, memberi arahan, dan motivasi, sekaligus membantu dalam menangani berbagai masalah yang dialami peserta didik baik seorang atau lebih. Seperti salah satu masalah yang dihadapi oleh peserta didik yaitu masalah prokrastinasi.

Prokrastinasi adalah menunda dengan sengaja kegiatan yang di inginkan walaupun mengetahui bahwa penundaannya dapat menghasilkan dampak buruk, seperti menunda mengerjakan tugas, penundaan belajar menghadapi ulangan maupun ujian, membaca, kinerja administrative, menghadiri pertemuan akademik/ mengikuti pembelajaran di kelas, serta menunda-nunda pekerjaan rumah (PR).

Satria M.Rafiko (2017), melakukan penelitian tentang Strategi Guru Bimbingan Dan Konseling Dalam Mengatasi Perilaku Prokrastinasi Akademik Siswa Di Man 2 Batu Sangkar Tahun 2016-2017,tujuan dalam penelitian ini adalah mengidentifikasi perilaku prokrastinasi akademik siswa, melakukan need assessment dan himpunan data. Hasilnya menunjukan bahwa guru mata pelajaran dan wali kelas, penyusunan rencana diantarannya: layananan informasi, layanan bimbingan kelompok, layanan konseling perorangan dan layanan 

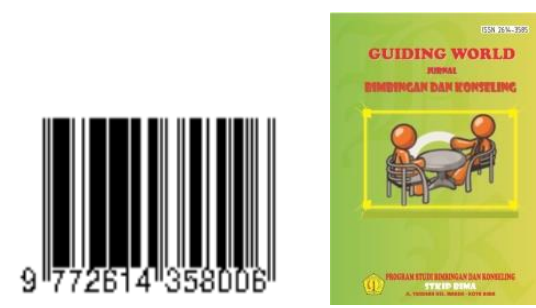

DOI: 1033627

Volume 03, Nomor 02

November 2020

E-ISSN: 2614-3585

konsultasi.Pelaksanaan keempat layanan tersebut sudah berjalan dengan baik di mana siswa mengikuti layanan dengan aktif.

Rahmanisa (2018), melakukan penelitian Tentang Konseling Behavioral Dalam Menangani Prokrastinasi Akademik Siswa MAN 2 Tahun 2017-2018, Tujuan penelitian untuk mengetahui tahap-tahap konseling behavioral dalam menangani prokrastinasi akademik yang dilakukan guru BK MAN 2 Yogyakarta adalah : 1) assesmen, mendapatkan data bahwa subjek menunda tugas disebabkan oleh faktor internal dan eksternal, 2) goal setting, tujuan konseling agar subjek mandiri dan bertanggung jawab, 3) technique implementation, teknik yang digunakan adalah desenttisasi positif dan penguatan positif dan hukuman, 4) evaluation termination,menghasilkan kominten dan kesadaran diri subjek, 5) feedback, menunjukan bahwa proses konseling tidak berhasil sehingga perlu adanya perbaikan dan penanganan yang lebih serius.

Suryadi (2017),Melakukan penelitian Tentang Layanan Bimbingan dan Konseling Belajar Untuk Mereduksi Prokrastinasi Akademik Siswa Boarding SMA IT Abu Bakar Yogyakarta, tujuan penelitian yaitu untuk mengidenfikasi perilaku prokrastinasi akademik siswa meliputi layanan dasar berfungsi sebagai layanan preventif dan pemeliharaan, layanan responsif berfungsi sebagai layanan kuratif yang spesifik digunakan dalam mereduksi prokrastinasi akademik siswa.

Berdasarkanobservasi dan wawancara pada peserta didik di SMA Negeri 2 Kota Bima masih terdapat beberapa peserta didik yang mengalami prokrastinasi, diantaranya tidak mengerjakan tugas, menganggap enteng/menunda mengerjakan tugas sampai saat terakhir untuk mengumpulkan tugas, sehingga berdampak pada turunya prestasi peserta didik.Oleh karena itu prokrastinasi merupakan masalah penting yang perlu mendapatkan perhatian karena berpengaruh pada peserta didikitu sendiri. prokrastinasi harus diatasi agar peserta didik mengembangkan potensi-potensi dirinya, menjadi manusia yang beriman dan bertaqwa kepada Tuhan yang Maha Esa, berahlak mulia, berilmu, cakap, kreatif, dan mandiri.

Berdasarkan uraian diatas, maka peneliti ingin mengetahui bagaimana Peran Guru Bimbingan Konseling Dalam Mengatasi Prokrastinasi Pada Peserta Didik dan mengangkat penelitian dengan judul Peran Guru Bimbingan dan Konseling Dalam Mengatasi Prokrastinasi Pada Peserta Didik di SMANEGERI 2 KOTA BIMA.

Berdasarkan uraian masalah tersebut di atas, maka rumusan masalah yang di angkat dalam penelitian ini adalah bagaimana peran guru bimbingan dan konseling dalam mengatasi prokrastinasi di SMA Negeri 2 Kota Bima?

Berdasarkan rumusan masalah tersebut maka tujuan yang ingin dicapai dalam penelitian ini adalah untuk mengetahui bagaimana peran guru bimbingan dan konseling dalam mengatasi prokrastinasi pada peserta didik di SMA Negeri 2 Kota Bima.

\section{KERANGKA TEORITIS DAN PENGEMBANGAN HIPOTESIS Guru Bimbingan dan Konseling}

a. Pengertian Guru Bimbingan dan Konseling

Winkel (2006: 172) Guru bimbingan dan konseling adalah tenaga professional, yang mencurahkan seluruh waktunya pada pelayanan bimbingan (full-time guidance counselor).

Guru bimbingan dan konseling adalah seorang tenaga professional yang memperoleh pendidikan khusus diperguruan tinggi dan mencurahkan seluruh waktunya pada layanan 


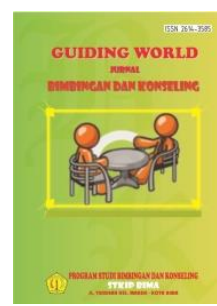

bimbingan dan konseling. Tenaga ini memberikan layanan-layanan bimbingan dan konseling kepada para siswa dan menjadi konsultan bagi staf sekolah dan orang tua (Winkel dan Hastuti, 2012:184).

Guru bimbingan dan konseling adalah seorang guru yang bertugas memberikan bantuan psikologis dan kemanusiaan secara ilmiah dan professional sehingga seorang guru bimbingan Dan konseling harus berusaha menciptakan komunikasi yang baik dengan murid dalam menghadapi masalah dan tantangan hidup (Sukardi,DK 2008).

Berdasarkan uraian diatas dapat di tarik kesimpulan bahwa guru bimbingan dan konseling adalah tenaga professional yang ikut berpartisipasi dalam mengarahkan, bertugas dan memberikan bantuan psikologis dan kemanusiaan secara ilmiah dan professional sehingga seorang guru bimbingan dan konseling memperoleh pendidikan khusus diperguruan tinggi dan mencurahkan seluruh waktunya pada layanan bimbingan dan konseling.

b. Tugas Guru Bimbingan dan Konseling

Menurut Permendikbud Nomor 15 Tahun 2018 "guru yang merangkap sebagai wali kelas, guru mata pelajaran dan guru Bimbingan dan Konseling (BK) memiliki tugas utama untuk mendidik, mengajar, membimbing, mengarahkan, menilai, dan mengevaluasi peserta didik, sedangkan dalam SK mendikbd No. 25 tahun 1995 tentang petunjuk teknis pelaksanaan jabatan fungsional guru dan angka kreditnya yang menggariskan bahwa tugas pokok guru pembimbing di sekolah: menyusun program bimbingan, yaitu rencana layanan bimbingan dan konseling dalam bidang bimbingan pribadi, belajar, social dan karir.

Tugas guru bimbingan dan konseling yaitu membantu peserta didik dalam :

1) Pengembangan kehidupan pribadi, yaitu bidang pelayanan yang membantu peserta didik dalam memahami, menilai bakat dan minat.

2) Pengembangan kehidupan sosial, yaitu bidang pelayanan yang membantu peserta didik dalam memahami dan menilai serta mengembangkan kemampuan hubungan sosial dan industrial yang harmonis, dinamis, berkeadilan dan bermartabat.

3) Pengembangan kemampuan belajar, yaitu bidang pelayanan yang membantu peserta didik mengembangkan kemampuan belajar untuk mengikuti pendidikan sekolah atau madrasah secara mandiri.

4) Pengembangan karir, yaitu bidang pelayanan yang membantu peserta didik dalam memahami dan menilai informasi, serta memilih dan mengambil keputusan karir.

c. Kompetensi Guru Bimbingan dan Konseling

Kompetensi merupakan seperangkat perilaku dari seseorang berupa sikap, karakteristik pribadi, keterampilan, kemampuan, serta pengetahuan yang mengarah kepada aspek kognitif,afektif dan psikomotorik yang mengarahkan seseorang untuk mencapai tujuan yang efisien.

Dalam Undang-Undang Nomor 14 Tahun 2005 tentang Guru dan Dosen (Depdiknas, 2005a), dan peraturan Pemerintah Nomor 19 tahun 2005 tentang Standar Nasional Pendidikan (Depdiknas,2005b), dikemukakan empat kompetensi pendidik sebagai agen pembelajaran. Kompetensi tersebut mencakup kompetensi pedagogik, kompetensi kepribadian, kompetensi profesional, dan kompetensi sosial.

Proses pembelajaran, yang dalam pelayanan konseling berbentuk proses konseling merupakan kondisi yang secara dinamis, strategis langsung dikembangkan oleh Guru 


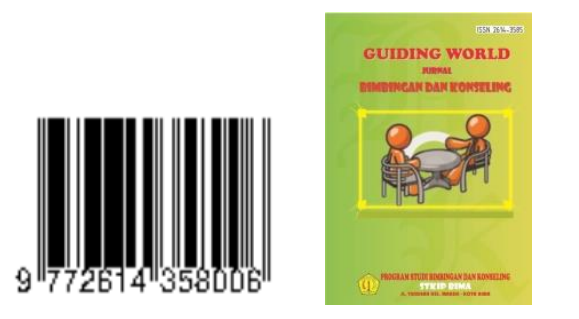

Bimbngan dan Konseling klien. Proses konseling inilah yang menjadi tugas pokok guru bimbingan dan konseling profesional. Untuk mampu mewujudkan proses konseling yang efektif guru bimbingan dan konseling dituntut menguasai berbagai kompetensi yang mendukung profesi guru bibingan dan konseling.

Kompetensi guru bimbingan dan konseling yang diaksud disini mengacu pada standar kompetensi konselor (SKK) yang terdapat dalam standar Kualifikasi Akademik dan Kompetensi Konselor (SKAKK) yang dirumuskan dalam Permendiknas No.27 Tahun 2008.

1) Standar Kompetensi Konselor

Dalam Permendiknas nomor 27 tahun 2008 yang dikutip dalam paying (2011:304) tentang standar Kualifikasi Akademik dan Kompetensi konselor (SKAKK), dijelaskan bahwa :

Sosok utuh kompetensi konselor mencakup kompetensi akademik dan professional sebagai satu keutuhan.Kompetensi akademik merupakan landasan ilmiah dari pelaksanaan pelayanan profesional bimbingan dan konseling, kompetensi akademik dan profesional konselor secara terintegrasi membangun keutuhan kompetensi pedagogik, kepribadian, sosial dan profesional.

Sesuai denganpermendiknas no.27 tahun 2008 tersebut dapat disimpulkan bahwa seorang guru bimbingan dan konseling harus memiliki keempat kompetensi yaitu: kompetensi pedagogik, kepribadian, sosial, dan profesional. Untuk lebih jelasnya keempat kompetensi tersebut akan dipaparkan di bawah.

a) Kompetensi Pedagogik

Pedagogik berarti segalausaha yang dilakukan oleh pendidik untuk membimbing anak muda menjadi manusia dewasa dan matang.Kompetensi pedagogik adalah kemampuan mengelola pembelajaran peserta didik yang meliputi pemahaman terhadap peserta didik, rancangan dan pelaksanaan pembelajaran, evaluasi hasil belajar, dan pengembangan peserta didik untuk mengaktualisasikan berbagai petensi yang dimilikinya (Mulyasa,2009 :75).Dalam hal ini kompetensi pedagogik yang harus dimiliki guru bimbingan dan konseling yaitu kemampuan dalam memberikan bimbingan belajar bagi peserta didik terutama peserta didik yang malas belajar.

Dalam Standar Kopetensi Konselor menurut permendiknas no.27 tahun 2008, kompetensi pedagogik dijabarkan menjadi beberapa indikator, yaitu:

1) Menguasai teori dan praksi pendidikan.

Tugas konselor adalah memberikan pelayanan kepada konseli..dengan Seorang guru bimbingan dan konseling harus bisa menguasai teori yang ada berdasarkan landasan keilmuannya sehingga teori tersebut dapat digunakan untuk bekal guru bimbingan dan konseling dalam memberikan pelayanan kepada peserta didik. Dengan teori yang matang maka kemampuan dalam memberikan layanan pun akan lebih optimal.

2) Mengaplikasikan perkembangan fisiologis dan psikologis serta prilaku konseli.

Dalam layanan konseling guru bimbingan dan konseling yang baik harus mengetahui dan mencatat setiap perkembangan yang ada yang terjadi pada konseli, baik yang bersifat fisiologis maupun psikologis.Data perkembangan 


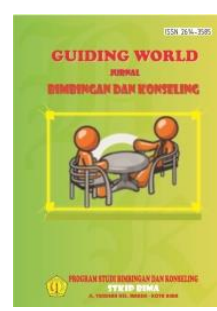

DOI: 1033627

tadi sangat berguna untuk menentukan pemberian layanan yang tepat dalam tahap konseling selanjutnya.

3) menguasai esensi pelayanan bimbingan dan konseling dalam jalur, jenis dan jenjang satuan pendidikan.

Setiap guru bimbingan dan konseling profesional dituntut untuk fleksibel menguasai esensi pelayanan bimbingan dan konseling dalam semua jalur, jenis dan jenjang satuan pendidikan.Karena ruang lingkup guru bimbingan dan konseling sangatlah luas dalam bidang pendidikan. Dengan dikuasainya esensi pelayanan bimbingan dan konseling tersebut maka guru bimbingan dan konseling akan siap ditugaskan di mana saja yang sesuai dengan jalurnya.

Kaitan kompetensi pedagogik dengan penelitian yang dilakukan peneliti adalah kompetensi pedagogik merupakan bagian dari komponen pembentuk profesionalisme konselor. Dengan memiliki kompetensi pedagogik yang baik guru bimbingan dan konseling mampu mengelola pembelajaran yang mendidik dan dialogis.

b) Kompetensi kepribadian

Kompetensi kepribadian adalah kompetensi yang berkaitan dengan prilaku yang memiliki nilai-nilai luhur sehingga terpancar dalam kehidupan sehari-hari. Guru bimbingan dan konseling harus mempunyai kepribadian yang mantap artinya mampu mengendalikan diri dan memberikan pelayanan bimbingan dan konseling kepada peserta didik yang membutuhkannya dengan menjaga kode etik profesi konselor.

Dalam Standar Kopetensi Konselor menurut permendiknas no.27 tahun 2008, kompetensi kepribadian dijabarkan menjadi beberapa indikator, yaitu:

1) Beriman Dan Bertakwa Kepada Tuhan Yang Maha Esa.

Di sila pertama pancasila menyebutkan bahwa Negara Indonesia berlandaskan ketuhanan yang Maha Esa.Konselor haruslah beriman dan bertaqwa kepada tuhan yang maha Esa. Sehingga menjadi pribadi religious yang dapat menentramkan diri sendiri dan orang lain terutama konseli.

2) Menghargai dan menjunjung tinggi nilai kemanusiaan, individualitas dan kebebasan memilih.

Manusia adalah mahluk sosial yang tidak dapat hidup sendiri tanpa bantuan dari orang lain. Sehingga nilai-nilai kemanusiaan, individualitas dan kebebasan memilih haruslah dijunjung tinggi.Begitupun dengan guru bimbingan dan konseling, harus mampu menghargai nilai kemanusiaan, individualitas dan kebebasan memilih setiap individu terutama konseli.

3) Menunjukan integritas dan stabilitas kepribadian yang kuat.

Guru bimbingan dan konseling harus memiliki kepribadian yang mantap, pribadi yang mantap dapat diwujudkan dalam integritas dan stabilitas kepribadian yang kuat. Tanpa integritas dan stabilitas kepribadian yang mengakibatkan guru bimbingan dan konseling terlihat plin plan dan menurunya minat dan kepercayaan konseli terhadap konselor.

4) Menampilkan kinerja berkualitas tinggi.

Salah satu cirri guru bimbingan dan konseling profesional adalah mampu menampilkan kinerja berkualitas tinggi. Dengan kinerja kualitas tinggi maka 


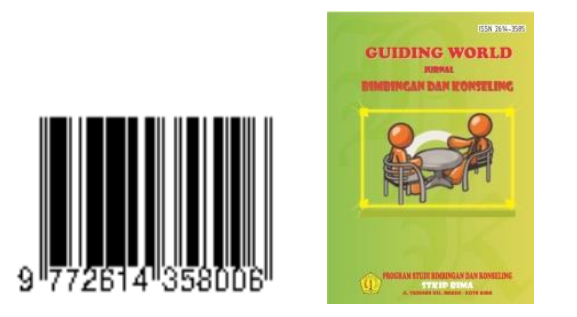

akan meningkatkan mutu pelayanan bimbingan dan konseling yang diberikan sehingga dapat lebih memuaskan para pengguna jasa layanan bimbingan dan konseling.

\section{Konsep Teori Prokrastinasi}

\section{a. Pengertian Prokrastinasi}

Menurut Lay (dalam wattimena, 2015), Prokrastinasi adalah menunda apa yang perlu dilakukan untuk mencapai tujuan tertentu hingga beberapa waktu ke depan karena hal tersebut dirasakan berat, tidak menyenangkan, atau kurang menarik.Sedangkan menurut Watson (Ghufron, 2003:15), anteseden prokrastinasi berkaitan dengan takut gagal, tidak suka pada tugas yang diberikan, menentang dan melawan kontrol, mempunyai sifat ketergantungan dan kesulitan dalam membuat keputusan. Brown dan Holzman (dalam Gufron,2003) bahwa prokrastinasi adalah seseorang yang mempunyai kecenderungan untuk menunda, atau tidak segera memulai suatu pekerjaan, menghadapi pekerjaan atau tugas.

Menurut ghufron (2010: 163-166 ) mengkategorikan faktor-faktor prokrastinasi. Faktor-faktor tersebut dibagi menjadi dua berdasarkan faktor internal dan eksternal. Adapun penjelasannya adalah sebagai berikut :

1) Faktor internal yaitu faktor-faktor yang terdapat dalam diri individu yang mempengaruhi terjadinya prokrastinasi.Faktor ini dapat dikelompokkan menjadi dua macam, yaitu kondisi fisik dan psikologis individu.

a) Kondisi fisik individu

Kondisi fisik individu berarti kondisi tubuh atau jasmani seseorang yang dapat dilihat dari kesehatannya. Ketika mendapat tugas, peserta didik yang kurang sehat tidak dapat mengerjkan tugas dengan maksimal, sehingga tugasnya pun tidak dapat selesai tepat waktu.

Fatigue atau kelelahan juga dapat berpengaruh terhadap prograstinasi. Menurut millgram (dalam ghufron,2010: 164) seseorang yang terkenal fatigue akan memiliki kecenderungan yang lebih tinggi untuk melakukan prokrastinasi dari pada yang tidak.

b) Kondisi psikologis individu

Kondisi psikologis adalah suatui kondisi jiwa seseorang, baik itu dari emosional, perasaan, sikap atau lain-lain yang bersangkutan dengan psikologisnya. Tinggi rendahnya motivasi yang dimiliki seseorang juga akan mempengaruhi terbentuknya perilaku penundaan.

2) Faktor eksternal adalah faktor-faktor diluar diri individu yang mempengaruhi prokrastinasi. Faktor-faktor tersebut terdiri dari:

a) Gaya pengasuhan orang tua

Hasil penelitian Ferrari \& ollivete (dalam ghufron,2010: 165) menemukan bahwa gaya pengasuhan ayah yang otoriter menyebabkan munculnya kecenderungan perilaku prokrastinasi, sedangkan gaya pengasuhan otoritatif tidak menyebabkan prokrastinasi. Berbeda dengan pengasuhan otoriter, orang tua yang mendidik anaknya dengan demokratis akan menyebabkan timbulnya sikap asertif, karena anak merasa diberi kebebasan dalam mengekspresikan diri sehingga memunculkan rasa percaya diri. 

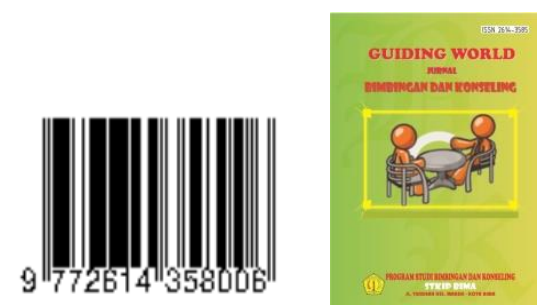

DOI: 1033627

Volume 03, Nomor 02

November 2020

E-ISSN: 2614-3585

b) Kondisi lingkungan

Prokrastinasi lebih banyak terjadi pada lingkungan yang rendah pengawasan dari pada lingkungan yang penuh pengawasan. Seseorang cenderung akan rajin mengerjakan tugas apabila ada yang mengawasi dirinya. Sebaliknya ketika tidak ada yang mengawasi, mereka merasa lebih bebas mau mengerjakan tugas sekarang atau nanti.Selain itu faktor teman bergaul dan masyarakat dapat pula mempengaruhi prokrastinasi.

Dari pendapat diatas dapat di tarik kesimpulan bahwa prokrastinasi adalah penundaan yang dilakukan untuk mencapai tujuan tertentu dalam menyelesaikan suatu pekerjaan yang dirasakan berat, tidak disukai dan tidak menyenangkan pada tugas yang diberikan.Dan prokrastinasi dapat dipengaruhi oleh faktor internal maupun eksternal. Faktor internal adalah faktor yang ada dalam diri individu, sedangkan faktor eksternal adalah faktor di luar diri individu, yang memunculkan perilaku prokrastinasi seseorang semakin meningkat.

\section{Teori Perkembangan Prokrastinasi}

Di sini akan dijelaskan beberapa teori perkembangan prokrastinasi :

a. Psikodinamik

Penganut psikodinamik beranggapa bahwa pengalaman masa kanak-kanak akan mempengaruhi perkembangan proses kognitif seseorang ketika dewasa, terutama trauma. Orang yang pernah mengalami trauma akan suatu tugas tertentu, misalnya gagal menyelesaikan tugas sekolahnya, akan cenderung melakukan prokrastinasi ketika dihadapkan lagi pada suatu tugas yang sama. Dia akan teringat kepada pengalaman kegagalan dan perasaan tidak menyenangkan yang pernah dialami.

b. Behavioristik

Penganut psikologi behavioristik beranggapan bahwa perilaku prokrastinasi muncul akibat proses pembelajaran.Seseorang melakukan prokrastinasi karena dia pernah mendapatkan punishment atas perilaku tersebut. Seorang yang pernah merasakan sukses dalam melakukan penundaan dalam tugas sekolah, cenderung akan mengulangi lagi perbuatannya. Sukses yang dia rasakan akan dijadikan reward untuk mengulangi perilaku yang sama pada masa yang akan datang.

c. Kognitif dan Behavioral-Kognitif

Ellis dan Knaus memberikan penjelasan tentang prokrastinasi dari sudut pandang cognitive-behavioral.Prokrastinasi terjadi karena adanya keyakinan irasional yang dimiliki oleh seseorang.Keyakinan irasional tersebut dapat disebabkan suatu kesalahan dalam mempersepsikan tugas sekolah.Seseorang memandang tugas sebagai sesuatu yang berat dan tidak menyenangkan.Oleh karena itu, seseorang merasa tidak mampu menyelesaikan tugasnya secara memadai sehingga menunda-nunda menyelesaikan tugas tersebut secara memadai.

\section{Ciri-ciri Prokrastinasi}

Burka dan Yuen (2008:8), menjelaskan ciri-ciri seorang pelakuprokrastinasi antara lain:

a. Prokrastinator lebih suka untuk menunda pekerjaan atau tugas- tugasnya.

b. Berpendapat lebih baik mengerjakan nanti dari pada sekarang, danmenundaPekerjaan adalah bukan suatu masalah.

c. Terus mengulang perilaku prokrastinasi 


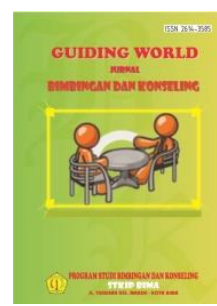

d. Pelaku prokrastinasi akan kesulitan dalam mengambil keputusan.

Penundaan untuk memulai maupun menyelesaikan kerja pada tugas yang dihadapi jadi siswa yang melakukan prokrastinasi tahu bahwa tugas yang dihadapinya harus segera diselesaikan, akan tetapi dia menunda-nunda untuk mulai mengerjakannya atau menundanunda untuk menyelesaikan sampai tuntas jika dia sudah mulai mengerjakan sebelumnya. Keterlambatan dalam mengerjakan tugas, jadi siswa yang melakukan prokrastinasi memerlukan waktu yang lebih lama daripada waktu yang dibutuhkan pada umumnya dalam mengerjakan suatu tugas.

Seorang prokrastinator menghabiskan waktu yang dimilikinya untuk mempersiapkan diri secara berlebihan, maupun melakukan hal-hal yang tidak dibutuhkan dalam penyelesaian suatu tugas, tanpa memperhitungkan keterbatasan waktu yang dimilikinya. Kadang-kadang tindakan tersebut mengakibatkan seseorang tidak berhasil menyelesaikan tugasnya secara memadai.Kelambanan, dalam arti lambannya siswa dalam melakukan suatu tugas dapat menjadi ciri yang utama dalam prokrastinasi.

Kesenjangan waktu antara rencana dan kinerja aktual, maksudnya siswa yang melakukan prokrastinasi mempunyai kesulitan untuk melakukan sesuatu sesuai dengan batas waktu yang telah ditentukan sebelumnya. Seorang prokrastinator sering mengalami keterlambatan dalam memenuhi deadline yang telah ditentukan, baik oleh orang lain maupun rencana-rencana yang telah ditentukan sendiri. Seseorang mungkin telah merencanakan untuk mulai mengerjakan tugas pada waktu yang telah ditentukan akan tetapi ketika saatnya tiba tidak juga melakukannya sesuai dengan apa yang telah direncanakan, sehingga menyebabkan keterlambatan maupun kegagalan untuk menyelesaikan tugas secara memadai dengan melakukan aktivitas lain yang lebih menyenangkan daripada melakukan tugas yang harusnya dikerjakan. Siswa yang melakukan prokrastinasi dengan sengaja tidak segera melakukan tugasnya, akan tetapi menggunakan waktu yang dia miliki untuk melakukan aktivitas lain yang dipandang lebih menyenangkan dan mendatangkan hiburan, seperti membaca (koran, majalah, atau buku cerita lainnya), nonton, ngobrol, jalan, mendengarkan musik, dan sebagainya, sehingga menyita waktu yang dia miliki untuk mengerjakan tugas yang harus diselesaikannya.

Jadi dapat disimpulkan bahwa ciri-ciri prokrastinasiadalah penundaan untuk memulai maupun menyelesaikan kerja pada tugas yang dihadapi, keterlambatan dalam mengerjakan tugas, kesenjangan waktu antara rencana dan kinerja aktual dan melakukan aktivitas lain yang lebih menyenangkan daripada melakukan tugas yang harus dikerjakan..

\section{Tujuan Tentang Prokrastinasi}

Ferrari (M.N.Ghufron, 2003:19), penundaan dilakukan dengan suatu cara untuk menghindari tugas yang dirasa tidak menyenangkan dan sulit untuk dilakukan. Prokrastinasi dilakukan untuk menghindari kegagalan dalam menyelesaikan pekerjaan, yang akan mendatangkan nilai negatif dalam dirinya atau mengancam self esteemnya sehingga seseorang menunda untuk melakukan sesuatu yang nyata yang berhubungan dengan tugasnya.

Penundaan disertai alasan yang kuat, mempunyai tujuan pasti sehingga tidak merugikan, bahkan berguna untuk melakukan suatu upaya konsumtif agar suatu tugas dapat diselesaikan dengan baik 

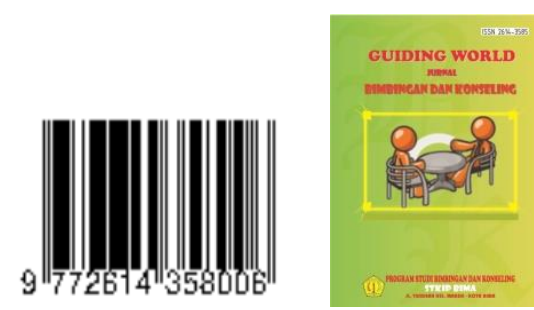

DOI: 1033627

Volume 03, Nomor 02

November 2020

E-ISSN: 2614-3585

\section{METODE}

\section{A. Pendekatan dan Jenis penelitian}

Jenis penelitian ini dapat dikategorikan dalam penelitian deskriptif dengan menggunakan pendekatan kualitatif, dengan alasan agar dapat menggali informasi yang mendalam mengenai objek yang diteliti.Metode deskriptif bertujuan untuk memberikan gambaran tentang gejala atau hubungan antara dua gejala atau lebih.Pendekatan yang digunakan dalam penelitian ini adalah pendekatan kualitatif yang berakar pada latar belakang ilmiah sebagai kebutuhan, mengandalkan manusia sebagai alat penelitian, memanfaatkan metode kualitatif analisi secara iduktif, mengarahkan sasaran penelitian pada usaha menemukan teori, lebih mementingkan proses dari pada hasil, memilih seperangkat kriteria untuk menulis keabsahan data, rencana peneliti bersifat sementara dan hasil penelitian disepakati oleh subjek penelitian.

Miles dan Huberman (1992) menjelaskan bahwa data kualitatif memiliki landasan kukuh atas deskripsi yang luas, serta memuat penjelasan tentang proses-proses yang terjadi dalam lingkup setempat.Dengan data kualitatif peneliti dapat memahami alur peristiwa secara kronologis, menilai sebab akibat dalam lingkup pikiran orang-orang setempat, dan memperoleh penjelasan yang banyak dan bermanfaat.

Sehubungan dengan pendapat para ahli diatas, rancangan yang digunakan dalam penelitian ini adalah jenis penelitian deskriptif kualitatif, jenis penelitian ini digunakan untuk SMA Negeri 2 Kota Bima sesuai dengan permasalahan yang diteliti yaitu tentang Peranan Guru Bimbingan dan Konseling dalam mengatasi prokrastinasi pada peserta didik.

Peran Guru BimbingandanKonseling dalam mengatasi prokrastinasi pada peserta didik di SMA Negeri 2 Kota Bima Tahun Pelajaran 2019/2020, sehingga diperoleh gambaran secara sistematis dengan menggunakan data yang factual.

Dalam penelitian ini, peneliti bertindak sebagai pengumpul data dan sebagai instrument aktif dalam upaya mengumpulkan data-data di lapangan. Sedangkan instrument pengumpulan data yang lain selain manusia adalah berbagai bentuk alat-alat bantu dan berupa dokumen-dokumen lainnya yang dapat digunakan untuk menunjang keabsahan hasil penelitian, namun berfungsi sebagai instrument pendukung. Oleh karena itu,untuk mendapatkan data-data yang valid dan objektif terhadap apa yang diteliti maka kehadiran peneliti secara langsung di lapangan sebagai tolak ukur keberhasilan untuk memahami kasus yang diteliti,tetapi hanya sebagai pengawas.

\section{B. Sumber Data}

MenurutNur Indrianto dan Bambang Supomo (2013:142) sumber data adalah Sumber data merupakan faktor penting yang menjadi pertimbangan dalam penentuan metode pengumpulan data disamping jenis data yang telah dibuat di muka. Maka dapat disimpulkan bahwa sumber data adalah faktor yang paling penting dalam penentuan metode pengumpulan data untuk mengetahui dari mana subjek data tersebut diperoleh. Sumber data derdiri dari :

1. Data primer

Menurut Husen Umar (2013:42) data primer merupakan data yang di dapat dari sumber pertama baik dari individu atau perseorangan seperti hasil dari wawancara atau hasil dari wawancara atau hasil pengisian kuesioner/angket yang biasa dilakukan oleh peneliti. Sedangkan menurut Nur Indrianto dan Bambang Supomo (2013:142) data primer merupakan sumber data penelitian yang diperoleh langsung dari sumber asli (tidak melalui media perantara). Dapat disimpulkan bahwa data primer 


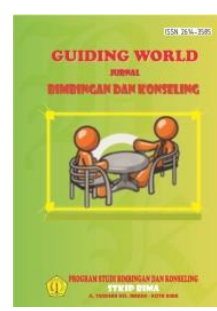

DOI: 1033627

merupakan data yang langsung dapat dan disajikan sebagai sumber dari penelitian dan pengamatan secara langsung pada objek atau tempat penulis melakukan penelitian. Data primer contohnya data yang diperoleh melalui pedoman wawancara. 2 orang peserta didik dan 2 guru Bimbingan dan Konseling.

2. Data Sekunder

Menurut Nur Indrianto dan Bambang Supomo (2013:143) data sekunder adalah sumber data penelitian yang diperoleh peneliti secara tidak langsung melalui media perantara (diperoleh dan dicatat oleh pihak lain). Dapat disimpulkan merupakan data yang diperoleh secara tidak langsung atau melalui sumber lain yang sudah tersedia sebelum penulis melakukan penelitian.Data sekunder adalah data yang diperoleh peneliti dari sumber yang sudah ada di SMA Negeri 2 Kota Bima. Misalnya catatan atau dokumentasi sekolah, absensi siswa dan lain-lain. Data sekunder ini untuk memperkuat penemuan dan melengkapi informasi yang telah dikumpulkan melalui wawancara langsung dengan guru bimbingan dan konseling di SMA Negeri 2 Kota Bima

\section{Prosedur pengumpulan data}

Pengumpulan data merupakan langkah yang sangat penting dalam penelitian, datadata tersebut dikumpulkan menggunakan tiga cara yaitu :

1. Metode Observasi yaitu pengumpulan data yang dilakukan dengan cara meninjau atau mengunjungi sekolah yang bersangkutan dan penulis melakukan pengamatan secara langsung untuk mencatat informasi yang berkaitan dengan masalah yang akan diteliti.Tujuan menggunakan metode ini untuk mencatat hal-hal, perilaku, perkembangan, dan sebagainya tentang peranan guru bimbingan dan konseling dalam mengatasi prokrastinasi di SMA Negeri 2 Kota Bima.

2. Wawancara yaitu proses memperoleh keterangan untuk tujuan penelitian dengan cara Tanya jawab, sambil bertatap muka antara si penanya dengan si penjawab dengan menggunakan alat yang dinamakan interview guide(panduan wawancara). Tujuan penulis menggunakan metode ini, untuk memperoleh data secara jelas dan kongkret tentang peranan guru bimbingandankonseling dalam mengatasi prokrastinasi pada peserta didik di SMA Negeri 2 Kota Bima, dalam penelitian ini peneliti akan mengadakan wawancara dengan guru bimbingandankonseling di SMA Negeri 2 Kota Bima.

3. Dokumentasi adalah pengumpulan data dengan meneliti catatan-catatan penting yang sangat erat hubungannya dengan obyek penelitian. Tujuan digunakan metode ini untuk memperoleh data secara jelas dan konkret tentang peranan guru bimbingan dan konseling di SMA Negeri 2 Kota Bima.

\section{Analisis data}

Teknikanalisis data merupakancara yang digunakanuntukmenguraikanketeranganketeranganatau data yang diperoleh agar data tersebutdapatdipahami, bukansajaoleh yang mengumpulkan data tetapijugaoleh orang lain. Analisis data-data diartikansebagaiperolehdarihasil interview, catatanlapangan, dandokumentasi, dengancaramengorganisasikankedalamkategori, menjabarkankedalam unit-unit, melakukansintesa, menyusunkedalampola, memilihmana yang pentingdan yang akandipelajari, danmembuatkesimpulansehinggamudahdipahami. 

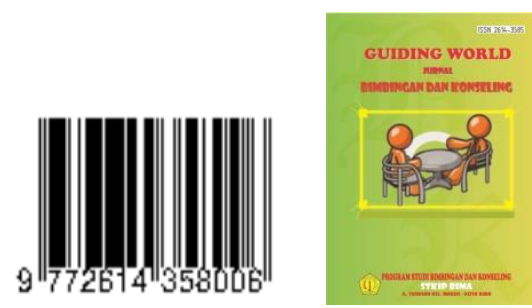

DOI: 1033627

Volume 03, Nomor 02

November 2020

E-ISSN: 2614-3585

Sementara Miles \&Huberman (1992:16), mengatakan "bahwaadabeberapaelemenpentingdalamanalisi data yang pentingdalamanalisis data kualitatif yang perludiingatolehsetiappenelitidalammelakukankegiatananalisis data sebagaiberikut :

1. Reduksi data

Reduksi data diartikan sebagai proses pemilihan, pemusatan perhatian pada penyederhanaan, pengabstrakan, dan transformasi dara kasar yang muncul dari catatan-catatan tertulis di lapangan. Reduksi data berlangsung terus-menerus selama proyek yang berorientasi penelitian kualitatif berlangsung. Antisipasi akan adanya reduksi data sudah tampak waktu penelitiannya memutuskan (seringkali tanpa disadari sepenuhnya) kerangka konseptual wilayah penelitian, permasalahan penelitian, dan pendekatan pengumpulan data mana yang dipilihnya. Selama pengumpulan data berlangsung, terjadilan tahapan reduksiselanjutnya (membuat ringkasan, mengkode, menelusur tema, membuat gugus, membuat partisi, membuat memo). Reduksidata/transformasi iniberlanjut terus sesudah penelian lapangan, sampai laporan akhir lengkaptersusun. Reduksi data merupakan bagian dari analisis. Reduksi data merupakansuatu bentuk analisis yang menajamkan, menggolongkan, mengarahkanmembuang yang tidak perlu, dan mengorganisasi data dengan carasedemikianrupa hingga kesimpulan-kesimpulan finalnya dapat ditarik dan diverifikasi.

2. DisplayData atauPenyajian Data

Miles \& Huberman membatasi suatu penyajian sebagai sekumpulan

informasi tersusun yang memberi kemungkinan adanya penarikan kesimpulandanpengambilan tindakan. Dengan demikian seorang penganalisis dapat melihat apa yang sedang terjadi dan menentukan apakah menarik kesimpulan yang benar ataukah terus melangkah melakukan analisis yang menurut saran yang dikisahkan oleh penyajian sebagai sesuatu yang mungkin berguna.

3. VerifikasiatauPenarikankesimpulan

Penarikan kesimpulan menurut Miles \&Huberman hanyalah sebagian dari satu kegiatan dari konfigurasi yang utuh. Kesimpulan-kesimpulan juga diverifikasi selama penelitian berlangsung. Verifikasi itu mungkin sesingkat pemikiran kembali yang melintas dalam pikiran penganalisis (peneliti) selama ia menulis, suatu tinjauan ulang pada catatan-catatan lapangan, atau mungkin menjadi begitu seksama dan menghabiskan tenaga dengan peninjauan kembali serta tukar pikiran di antara teman sejawat untuk mengembangkan kesepakatan intersubjektif atau juga upaya-upaya yang luas untuk menempatkan salinan suatu temuan dalam seperangkat data yang lain. Singkatnya, makna-makna yang muncul dari data yang lain harus diuji kebenarannya, kekokohannya, dan kecocokannya, yakni yang merupakan validitasnya. Kesimpulan akhir tidak hanya terjadi pada waktu proses pengumpulan data saja, akan tetapi perlu diverifikasi agar benarbenar dapat dipertanggungjawabkan. 


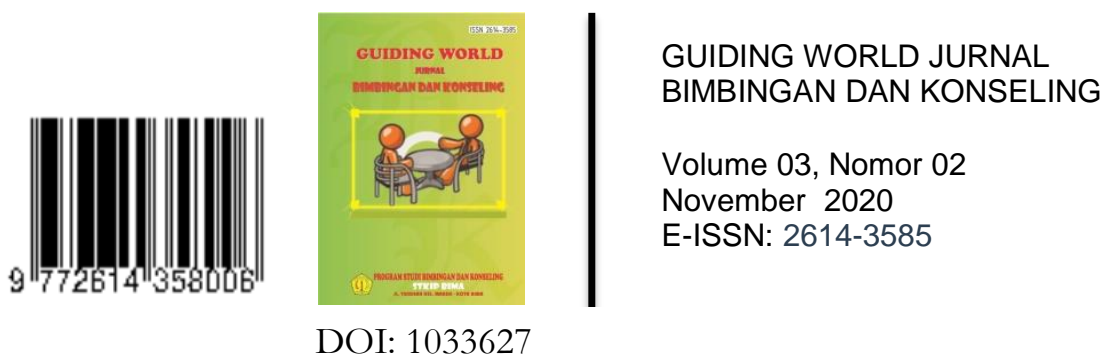

\section{HASIL PENELITIAN DAN PEMBAHASAN}

\section{A. Paparan Data}

1. Keadaan SMA Negeri 2 Kota Bima

SMAN 2 Kota Bima adalah sekolah yang sebelumnya bernama Sekolah Menengah Persiapan Pembangunan disingkat SMPP. SMPP berdiri tahun 1975 dengan surat keputusan Menteri Pendidikan dan Kebudayaan Republik Indonesia Nomor: 0283/O/1975 tanggal 27 Nopember 1975 dan diresmikan pembukaannya pada tanggal 14 Januari 1976.

Pada tahun 1985 tepatnya tanggal 21 Oktober 1985 Sekolah Menengah Persiapan pembangunan (SMPP) berganti nama menjadi Sekolah Menengah Atas (SMA) Negeri 2 Kabupaten Bima melalui surat keputusan Menteri Pendidikan dan Kebudayaan Republik Indonesia Nomor: 0353/O/1985 tanggal 21 Oktober 1985 dan seiring dengan pemekaran wilayah Kabupaten Bima dan Pemerintah Kota Bima maka sekarang bernama SMA Negeri 2 Kota Bima.

SMAN 2 Kota Bima terletak di jantung Kota Bima tepatnya berada di jalan Garuda Bima, Kelurahan Lewirato, Kecamatan Mpunda Kota Bima. Luas keseluruhan lingkungan SMAN 2 Kota 5,20 Ha sesuai surat Bupati Kepala Daerah Tingkat II Bima tanggal 23 Oktober 1973 Nomor:Pem.II/2/2112 tentang Pergantian tanah untuk bangunan Sekolah menengah Pembangunan Persiapan Bima. Masa pendidikan di SMA Negeri 2 Kota Bima ditempuh dalam kurun waktu 3 tahun, sama seperti pendidikan SMA di indonesia pada umumnya, di tempuh mulai dari kelas X sampai dengan kelas XII yang terdiri dari 3 jurusan yaitu ipa,ips,bahasa. Dengan kata lain sekolah ini banyak diminati oleh orang tua atau wali murid untuk menyekolahkan anak mereka ke jenjang pendidikan menengah atas.

SMA Negeri 2 Kota Bima mempunyai guru-guru yang berkompempeten di bidangnya agar dapat memberikan pelayanan yang baik bagi peserta didik. Jumlah seluruh guru adalah 86 orang, dengan rincian 59 guru tetap (PNS) dan 27 orang guru honorer.

2. Keadaan Sarana Dan Prasarana

SMA Negeri 2 Kota Bima memiliki sarana dan prasarana yang menunjang kegiatan belajar mengajar diantaranya : Memiliki 28 ruangan kelas, 1 ruangan laboratorium IPA, 1 ruangan Komputer, 1 ruangan perpustakaan, 1 ruangan TU, 1 ruangan musholah, 1 ruangan aula, 1 ruangan osis, 1 ruangan UKS, 4 ruangan kantin, 1 lapangan voly, 1 lapangan basket.

\section{B. Hasil Penelitian}

\section{Observasi}

Penelitian mulai melakukan observasi pada bulan September 2020 sampai dengan bulan oktober 2020 dalam kurung waktu 2 (dua) bulan. Selama melakukan penelitian tentang peran guru bimbingan dan konseling dalam mengatasi prokrastinasi pada peserta didik di SMA Negeri 2 Kota Bima. Hasil penelitian yang pernah peneliti lakukan pada tanggal 21 september 2020 mengungkapkan bahwasanya sebagian peserta didik ada yang menunda mengerjakan tugas. Hal itu terlihat dari beberapa peserta didik yang tidak mengerjakan tugas dengan alasan sedang sakit. Hal itu terlihat dari beberapa peserta didik yang berada di dalam 


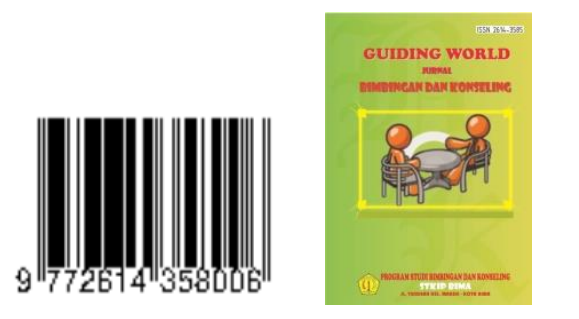

kelas pada saat kegiatan belajar mengajar berlangsung guru mata pelajaran memberi tugas tetapi tidak di kerjakan dikarenakan dirinya kurang percaya diri untuk mengerjakan tugas.

Penelitian selanjutnya pada tanggal 25 september 2020 peneliti menemukan beberapa peserta didik yang malas mengerjakan tugas karena lebih mementingkan pekerjaan lain ketimbang mengerjakan tugas.

Berdasarkan observasi dan wawancara peneliti menemukan beberapa peserta didik yang menunda mengerjakan tugas sehingga meminta bantuan kepada guru bimbingan dan konseling untuk memberikan motivasi dan pemahaman tentang dampak dari menunda mengerjakan tugas pada peserta didik. Setelah diberikan motivasi dan pemahaman tentang dampak menunda mengerjakan tugas oleh guru bimbingan dan konseling dengan begitu akan berdampak pada prestasi belajar rendah dan nilai peserta didik.

2. Wawancara

Berdasarkan hasil wawancara yang dilakukan oleh peneliti dengan Ibu Sri Niningsih, S.Pd selaku sekretaris koordinator Bimbingan dan Konseling di SMA Negeri 2 Kota Bima Tentang Ketika guru bimbingan dan konseling menemukan peserta didik yang sering menunda mengerjakan tugas dengan alasan sering sakit apa yang akan dilakukan?

"Sebagai guru bimbingan dan konseling yang dilakukan yaitu memberikan solusi dengan cara mengobati peserta didik dengan sarana yang telah di sediakan seperti obat-obatan. apabila sakit peserta didik parah, disarankan untuk berobat ke rumah sakit atau dokter"(Wawancara, 28 september 2020 pukul 10.00 Wita).

Berdasarkan hasil wawancara bahwa peserta didik yang sering menunda mengerjakan tugas dengan alasan sering sakit yang dilakukan guru bimbingan dan konseling dengan memberikan pertolongan $\mathrm{p} 3 \mathrm{k}$ atau memberikan pertolongan dengan obat-obatan yang sudah di sediakan oleh sekolah di ruang uks.

Kemudian dilakukan wawancara dengan Ibu Herlina S.Pdselaku guru bimbingan dan konseling menyatakan bahwa:

"Yang saya lakukan adalah mengidentifikasi masalahnya terlebih dahulu, apa bila ada laporan dari wali kelas atau guru mata pelajaran maka peserta didik yang mengalami prokrastinasi tersebut di panggil dan di bimbing untuk mengetahui alasan yang sebenarnya untuk menunda mengerjakan tugas" (Wawancara, 30 september 2020 pukul 09.05 Wita).

Berdasarkan hasil wawancara di atas bahwa yang dilakukan oleh guru bimbingan dan konseling yaitu mengidentifikasi masalah terlebih dahulu kemudian diberikan solusi untuk pengobatan pada peserta didik.

Dari kedua pendapat guru bimbingan dan konseling tentang ketika guru bimbimbingan dan konseling menemukan peserta didik yang sering menunda mengerjakan tugas dengan alasan sering sakit, yang dilakukan oleh guru bimbingan dan konseling yaitu mengidentifikasi masalah yang dialami peserta didik sehingga 


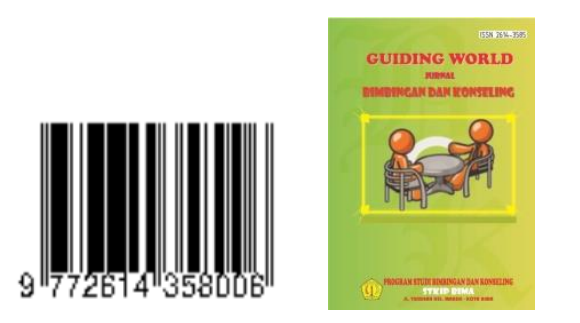

menunda mengerjakan tugas setelah itu diberikan bimbingan, apabila peserta didik sakit, akan diberikan pertolongan sesuai dengan sakit yang dialami peserta didik, apabila sakitnya parah maka guru bimbingan dan konseling mengambil alih untuk menyerahkan peserta didik kepada orang tua agar di berikan pengobatan lebih lanjutan,

Kemudian peneliti melakukan wawancara dengan Ibu Sri Niningsih S.Pd Tentang Apa saja faktor-faktor yang mempengaruhi terjadinya prokrastinasi pada peserta didik?

"Ada faktor internal dan faktor eksternal, faktor internal masalah pribadi peserta didik, ketika ada masalah sebagian peseta didik lebih memilih untuk memendamnya sendiri, dan berpengaruh terhadap pikirannya sehingga membuat peserta didik berlarut-larut memikirkan masalahanya, sehingga menyebabkan peserta didik jatuh sakit. dan pola asuh orang tua sangat berpengaruh terhadap prestasi belajar anak, pergaulan teman sebaya jugamempengaruhi terjadinya prokrastinasi karena ajakan teman untuk bermain akan membuat peserta didik tidak mengerjakan tugas" (Wawancara 28 septemer 2020).

Berdasarkan hasil wawancara diatas bahwa faktor internal yang ada dalam diri individu dan faktor eksternal yang ada di luar diri individu sangat mempengaruhi terjadinya prokrastinasi, apa bila bila peserta didik tertutup maka orang lain tidak akan mengetahui setiap permasalahan yang dialaminya sehingga akan berpengaruh terhadap kesehatannya. kemudian pola asuh orang tua juga mempengaruhi terjadinya prokrastinasi, seperti didikan orang tua,dan sikap orang tua sangat mempengaruhi terjadinya prokrastinasi. Lingkungan dan pergaulan teman sebaya juga mempengaruhi sikap peserta didik.

Kemudian peneliti melakukan denga Ibu Herlina S.Pd mengatakan bahwa:

"Faktor internal dan eksternal, pola asuh orang tua akan menjadi acuan utama untuk anak-anaknya untuk disiplin dalam mengerjakan segala hal, baik di lingkungan sekolah, keluarga dan masyarakat tergantung pola asuh orang tua, pergaulan dengan teman sekolah atau teman di luar lingkungan sekolah juga mempengaruhi terjadinya prokrastinasi" (Wawancara 30 september 2020).

Berdasarkan hasil wawancara diatas bahwa ada dua faktor yang mempengaruhi terjadinya prokrastinasi yaitu faktor internal dan faktor eksternal. Faktor internal yaitu faktor yang ada dalam diri peserta didik sedangkan faktor eksternal adalah faktor yang terdapat di luar diri peserta didik.

Dari kedua pendapat guru bimbingan dan konseling tentang apa saja faktorfaktor yang mempengaruhi terjadinya prokrastinasi, ada faktor internal dan faktor eksternal, faktor internal adalah faktor kondisi fisik individu dan psikologis individu, ketika peserta didik mendapat tugas, kondisi kesehatan kurang sehat sehingga peserta didik tidak dapat menyelesaikan tugas. Tinggi rendahnya motivasi yang dimiliki peserta didik akan mempengaruhi terjadinya penundaan mengerjakan 


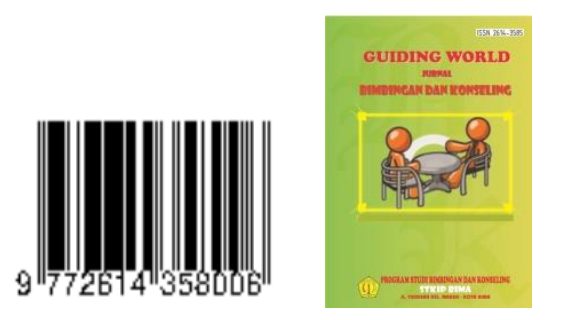

tugas. Pola asuh orang tua dan lingkungan sangat mempengaruhi terjadinya prokrastinasi.

Kemudian peneliti melakukan wawancara dengan Ibu Sri Niningsih S.Pd Tentang Bagaimana cara ibu mengatasi peserta didik yang memiliki kecemasan yang berlebihan ketika menunda mengerjakan tugas?

"Yang akan saya lakukan adalah memberikan motivasi untuk membangun semangat peserta didik untuk meningkatkan prestasi belajar" (Wawancara 28 september 2020).

Berdasarkan hasil wawancara bahwa yang akan dilakukan yaitu memberikan motivasi agar sakit yang dialami cepat membaik, tidak memberatkan pikiran peserta didik tentang tugas yang ada.

Hal senada juga diungkapkan oleh Ibu Herlina S.Pdmengatakan bahwa:

"Yangdilakukan yaitu memberikan pemahaman dampak prokrastinasi, dan memberikan suport bahwa peserta didik tersebut bisa mengerjakan tugas yang diberikan" (Wawancara 30 september 2020).

Berdasarkan hasil wawancara bahwa guru bimbingan dan konseling memberikan pemahaman tentang prokrastinasi kemudian di berikan pemahaman dari dampak menunda menegerjakan tugas, dan memberikan suport agar peserta tidak lagi menunda-nunda mengerjakan tugas.

Dari kedua pendapat guru bimbingan dan konseling tentang bagaimana cara guru bimbingan dan konseling mengatasi peserta didik yang memiliki kecemasan yang berlebihan ketika menunda mengerjakan tugas, cara yang di lakukan memberikan motivasi, tidak memberatkan peserta didik dengan tugas yang ada, memberikan semangat, memberikan support untuk meningkatkan prestasi belajar dan memberikan pemahaman dari dampak menunda mengerjakan tugas pada peserta didik.

Peneliti melakukan wawancara dengan Ibu Sri Niningsih S.Pd

Tentang Apakah guru bimbingan dan konseling melibatkan pihak lain dalam menanggani peserta didik yang mengalami prokrastinasi?

"Iya, saya melibatkan orang tua peserta didik karena tanpa adanya kerja sama dengan orang tua untuk membimbing dan memberikan motivasi kepada peserta didik, bimbingan yang diberikan oleh guru bimbingan dan konseling akan sia-sia" (Wawancara 28 september 2020).

Berdasarkan hasil wawancara bahwa guru bimbingan dan konseling melibatkan orang tua dalam menanggani peserta didik yang mengalami prokrastinasi. 


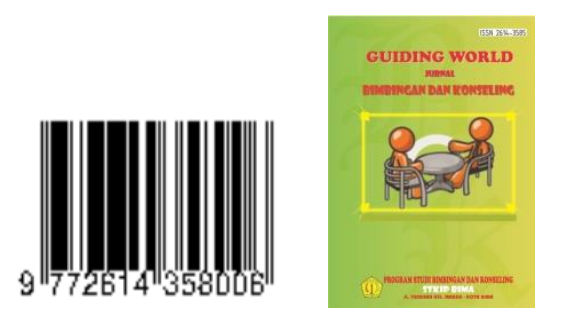

Kemudian wawancara dengan Ibu Herlina S.Pd menyatakan bahwa:

"Iya, saya sebagai guru bimbingan dan konseling tentu membutuhkan bantuan dari orang lain terutama orang tua peserta didik tersebut" (Wawancara 30 september 2020).

Berdasarkan hasil wawancara di atas dapat di simpulkan bahwa guru bimbingan dan konseling melibatkan pihak lain dalam menanggani peserta didik yang mengalami prokrastinasi yaitu orang tua peserta didik.

Dari kedua pendapat guru bimbingan dan konseling tentang apakah guru bimbingan dan konseling melibatkan pihak lain dalam menanggani peserta didik yang mengalami prokrastinasi, guru bimbingan dan konseling juga melibatkan pihak lain yaitu orang tua peserta didik dalam membantu mengurangi terjadinya prokrastinasi.

Peneliti melakukan wawancara dengan Ibu Sri Niningsih S.PdTentang Strategi atau Cara apa yang telah guru bimbingan dan konseling dalam mengatasi prokrastinasi pada peserta didik tersebut?

"Yang dilakukan oleh saya yaitu melihat nilai peserta didik tersebut, dari awal pengumpulan, pertengahan pengumpulan dan sampai akhir pengumpulan tugas ada nilai tersendiri yang diberikan oleh tiap-tiap guru mapel, peserta didik yang sering tidak mengumpulkan tugas di laporkan ke guru bimbingan dan konseling untuk di bina dan diberikan bimbingan khusus pada peserta didik yang bersangkutan" (Wawancara 28 september 2020).

Berdasarkan hasil wawancara cara yang telah dilakukan oleh guru bimbingan dan konseling yaitu melihat nilai dari tiap-tiap guru mapel, apa bila ada peserta didik yang sering tidak mengumpulkan tugas akan diberi bimbingan khusus.

Kemudian wawancara dengan Ibu Herlina S.Pd menyatakan bahwa:

"Apa bila ada laporan dari wali kelas tentang peseta didik yang sering menunda mengerjakan tugas atau yang tidak mengumpulkan tugas, peserta didik tersebut di panggil, di berikan wawancara konseling, dan diberi bimbingan sesuai dengan permasalahannya" (Wawancara 30 september 2020).

Berdasarkan hasil wawancara bahwa peserta di di bina, diberikan bimbingan sesuai dengan permasalahan yang di alami oleh peserta didik tersebut.

Dari kedua pendapat guru bimbingan dan konseling diatas cara yang telah guru bimbingan dan konseling berikan yaitu peserta didik yang sering tidak mengumpulkan tugas di panggi, di identifikasi kemudian diberikan bimbingan sesuai dengan permasalahan yang di alami.

Dalam hal ini peneliti melakukan wawancara dengan Adam jawari selaku siswa kelas XI IIS 3 yang peneliti wawancarai di ruangan kelas pada jam 11.10 pada tanggal 5 oktober 2020 bagaimana menurut peserta didik dengan adanya peranan guru bimbingan dan konseling dalam mengatasi prokrastinasi? 


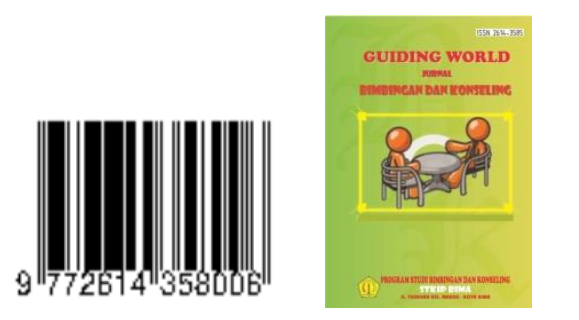

"Dengan adanya guru bimbingan dan konseling sangat membantu peserta didik dalam meningkatkan motivasi belajar"

Kemudian diungkapkan oleh Sahrul akbar selaku siswa kelas XI IIS 2 yang diwawancarai pada jam 09.05 di ruangan kelasnya pada tanggal 8 oktober 2020 menyatakan bahwa :

"Dengan adanya guru bimbingan dan konseling di sekolah membantu peserta didik memberi arahan, motivasi, bimbingan dan membantu memecahkan masalah peserta didik".

Berdasarkan hasil wawancara diatas dapat di simpulkan bahwa peran guru bimbingan dan konseling yaitu memberikan motivasi, arahan, bimbingan dan membantu peserta didik dalam meningkatkan prestasi belajar.

Peneliti melakukan wawancara dengan Adam jawari selaku siswa kelas XI IIS 3 yang peneliti wawancarai di ruangan kelas pada jam 11.10 pada tanggal 5 oktober 2020Bagaimana perkembangan peserta didik setelah guru bimbingan dan konseling memberikan bimbingan dan motivasi?

"Setelah diberikan motivasi saya jadi bersemangat dalam mengerjakan setiap tugas yang diberikan.

Hal senada juga diungkapkan oleh Sahrul akbar selaku siswa kelas XI IIS 2 yang diwawancarai pada jam 09.05 di ruangan kelasnya pada tanggal 8 oktober 2020 menyatakan bahwa :

"Setelah diberi bimbingan saya jadi memahami dampak dari menunda mengerjakan tugas, dan ternyata membuahkan hasil yang positif.

\section{Pembahasan}

Peran Guru Bimbingan dan Konseling yaitu bertanggung jawab untuk membimbing, memberi arahan, dan motivasi, sekaligus sebagai seorang pendidik yang memiliki tugas membantu siswa dalam menangani berbagai masalah yangdialami peserta didik baik seorang atau lebihdilingkungan sekolah maupun diluar lingkungan sekolah, seperti salah satu masalah yang dihadapi oleh peserta didik yaitu masalah prokrastinasi.Dalam hal ini guru bimbingan dan konseling sangat dibutuhkan untuk mengatasi dan meminimalisir prokrastinasi.

Prokrastinasi merupakan suatu penundaan tugas yang dilakukan peserta didik hingga beberapa waktu kedepan karena tugas yang dirasanya terlalu berat dan dirasa tidak menyenangkan baginya. Menurut Watson (Ghufron,2003:15), prokrastinasi berkaitan dengan takut gagal, tidak suka pada tugas yang diberikan, menentang dan melawan kontrol, mempunyai sifat ketergantungan dan kesulitan dalam membuat keputusan. Dalam hal ini, peran guru bimbingan dan konseling sangat dibutuhkan, dengan menggunakan layananlayanan tertentu sehingga dapat membantu peserta didik mengenal dirinya dan kemampuan yang dimilikinya sehingga peserta didik menjadi lebih percaya diri lagi di dalam menyelesaikan tugasnya. 


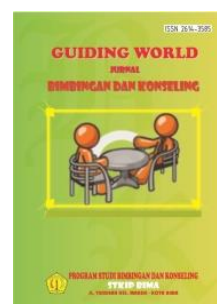

Jadi tujuan dari adanya peran guru bimbingan dan konseling dalam mengatasi prokrastinasi pada peserta didik yaitu untuk membantu peserta didik dalam mengembangkan pemahaman dan penguasaan kemampuan yang dimilikinya, berinteraksi di lingkungan baik lingkungan keluarga maupun sekolah untuk mencapai kesuksesan belajar dalam mengambil keputusan.Selain itu peran guru bimbingan dan konseling memberikan layanan bimbingan dan konseling kepada peserta didik agar lebih terarah dalam mengatasi masalah yang dihadapi peserta didik tersebut.

Guru bimbingan dan konseling memiliki tugas dan tanggung jawab dalam melaksanakan bimbingan dan konseling terhadap peserta didik yang sesuai dengan kebutuhan memahami diri dan lingkungan secara objektif dan dinamis, mengarahkan diri untuk kegiatankegiatan yang berguna sesuai dengan kebutuhan. Sebagai guru bimbingan dan konseling harus memiliki strategi dan tehnik-tehnik dalam memberikan pemahaman tentang akibat dari menunda mengerjakan tugas yang dibutuhkan oleh peserta didik di dalam menyikapi prokrastinasi. Dengan adanya guru bimbingan dan konseling menjadikan peserta didik mandiri dalam belajar, meningkatkan motivasi belajar, mengurangi malas, cara efektif memahami suatu mata pelajaran, semangat belajar, cara belajar atau metode yang efektif dan meningkatkan kepercayaan diri. Guru bimbingan dan konseling bertujuan membantu memberikan konseling kepada peserta didik yang mengalami masalah dan juga kesulitan dengan prestasi belajar di sekolah, dan membantu peserta didik dalam mencari jalan keluar yang tepat.

Berdasarkan hasil penelitian tentang peran guru bimbingan dan konseling dalam mengatasi prokrastinasi pada peserta didik di SMA Negeri 2 Kota Bima, peneliti dapat menyimpulkan bahwa peran guru bimbingan dan konseling dalam mengatasi prokrastinasi pada peserta didik dengan cara memberikan bimbingan dan motivasi terhadap peserta didik, guru bimbingan dan konseling berperan penting dalam mengatasi prokrastinasi karena jika guru mata pelajaran memberikan tugas tapi peserta didik tersebut malas atau menunda-nunda mengerjakan tugas nya maka disitu guru mata pelajaran mengalihkan peserta didik kepada guru bimbingan dan konseling agar di berikan motivasi, bimbingan, dorongan, dan arahan terhadap peserta didik tersebut. Setelah peserta didik di berikan motivasi, bimbingan, dorongan, dan arahan untuk tidak menunda-nunda mengerjakan tugas, menjadikan peserta didik percaya diri dengan kemampuan yang dimiliki, guru bimbingan dan konseling berharap peserta didik tidak lagi mengulangi untuk menunda-nunda mengerjakan tugas karena akan sangat berpengaruh pada nilai rendah.

\section{PENUTUP}

Adapun kesimpulan yang dapat peneliti sajikan dalam penelitian adalah peran guru Bimbingan dan Konseling dalam mengatasi prokrastinasi pada peserta didik yang ditandai dengan perilaku awal. Yaitu menunda-nunda mengerjakan tugas, setelah diberikan motivasi, pemahaman dan bimbingan ternyata membuahkan hasil yang positif, peserta didik jadi mengetahui akibat dari menunda-nunda mengerjakan tugas dan menjadikan peserta didik percaya diri dengan kemampuan yang dimiliki mereka,guru bimbingan dan konseling juga berperan memberikan bantuan, motivasi, mendidik, mengajar, membimbing, mengarahkan, menilai,mengevaluasi, dan membantu peserta didik dalam mengambil keputusan perubahan hidupnya. 


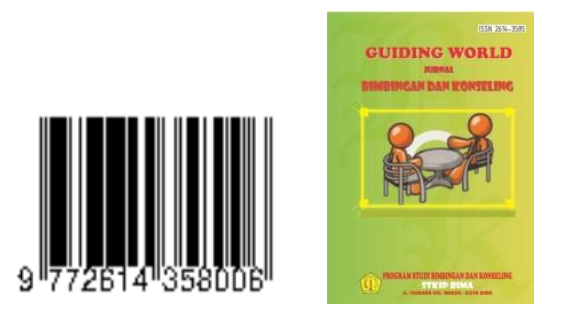

Ellis dan Knaus memberikan penjelasan tentang prokrastinasi dari sudut pandang cognitive-behavioral. Prokrastinasi terjadi karena adanya keyakinan irasional yang dimiliki oleh seseorang. Keyakinan irasional tersebut dapat disebabkan suatu kesalahan dalam mempersepsikan tugas sekolah. Seseorang memandang tugas sebagai sesuatu yang berat dan tidak menyenangkan. Oleh karena itu, seseorang merasa tidak mampu menyelesaikan tugasnya secara memadai sehingga menunda-nunda menyelesaikan tugas tersebut secara memadai.berlebihan.

\section{DAFTAR PUSTAKA}

Achmad Juntika Nurihsan. 2009. Bimbingan \& Konseling. Bandung: Refika Aditama. Alex Sobur.

Arfan, Lubis Ikhsan. 2011. Akutansi keperilakuan, Cetakan Kedua. Jakarta: Salemba Empal.

Burka, JB, L.M. Yuen. 2008. Procrastination, Why You Do It, What to Do About It Now. United States of America : Da Capo Press.

Ghufron. M.N. (2003). Hubungan Kontrol Diri dan Persepsi Remaja terhadap Penerapan Disiplin Orang tua terhadap Prokrastinasi Akademik. Tesis. Jogjakarta: Fakultas Psikologi Universitas Gadjah Mada.

Indrianto, Nurdan Supomo, Bambang. 2013. Metodologi Akutansi \& Manajemen. Yogyakarta: BPFE.

Knaus,W. 2010. End Procrastination now. United State: The Mc Graw _Hill Companies.

Kartadinata, Sunaryo.1996. Arah dan Tantangan Bimbingan dan Konseling Profesional. Available at file.upi.edu (accessed 04/03/2012)

Miles, M.B \& Huberman, Analisis Data Kualitatif. Terjemahan oleh Tjetijep Rohendi Rohadi. Jakarta: Universitas Indonesia Press, 1992.

Mulyasa,E, 2009. Praktik Penelitian Tindakan kelas. Bandung : PT. Remaja Rosda karya.

Munandir, 1996. Program Bimbingan karir di sekolah. Jakarta : Depdikbud.

M.N. Ghufron. 2003. Hubungan Prokrastinasi dan Kontrol Diri (On-line)

Natawidjaja, R, 2006 "Pengembangan Program Pendidikan Akademik dan Profesi Bimbingan dan Konseling pada Sekolah Pasca sarjana”. Makalah Pada Seminar Nasional. Bandung.

Prayitno, "Dasar teori dan Praktis Pendidikan, Jakarta : Grasindo 2009.

Sukardi. 2008. Pengantar Pelaksanaan Program Bimbingan dan Konseling di Sekolah. Jakarta: Rineka Cipta.

Soerjono Soekanto,2009:212-213, Peranan Sosiologi Suatu Pengantar, Edisi Baru, Rajawali Pers, Jakarta.

Sukandarrumidi. 2006. Metodologi Penelitian : Petunjuk Praktis Untuk Peneliti Semula. Yogyakarta : Gadja Mada University Press.

Sugiyono 2010. Metode Penelitian Kuanti Kualitatif \& RND. Bandung: Alfabeta.

Strauss, Anselm danYuliel Corbin. 2007. Dasar-Dasar Penelitian kualitatif. Yogyakarta: Pustaka Pelajar.

Usman, Husaini. 2013. Manajemen (Teori, Praktek dan Riset Pendidikan) Jakarta: Bumi Aksara. 
DOI: 1033627

Volume 03, Nomor 02

November 2020

E-ISSN: 2614-3585

W.S.Winkel,dan M.M Sri Hastuti, Bimbingan dan Konseling di Institusi Pendidikan, (Yogyakarta: Media Abadi, 2012), Halaman 184.

Wattimena,E.P. 2015. Hubungan antara perfeksionisme dengan prokrastinasi akademik dalam menyelesaikan skripsi pada mahasiswa di fakultas psikologi. 